\title{
IMPACT OF MOTOR VEHICLE FLEET ON AIR POLLUTION IN THE REPUBLIC OF KOSOVO
}

\author{
Kumbim Shala $^{{ }^{*}}$, Altin Dorri ${ }^{2}$ \\ ${ }^{1 *}$ Unversity of Pristina, Faculty of Mechanical Engineering, Prishtina, Kosovo; \\ ${ }^{2}$ Polytechnic University of Tirana, Faculty of Mechanical Engineering, Tirana, Albania; \\ *Corresponding Author Kumbim Shala, e-mail: kumbim.shala@uni-pr.edu; adorri@fim.edu.al;
}

Received March 2021; Accepted April 2021; Published May 2021;

DOI: https://doi.org/10.31407/ijees11.304

\begin{abstract}
Mobility is considered the basic activity in social and economic life. Motorized traffic is the most massive activity within most countries. The Republic of Kosovo, in the absence of the extension and coverage of the territory with the collective transport network, remains the place where cars are used in almost every destination and purpose of mobility. The environmental and health effects of car use are already known throughout the globe, so monitoring and analysis to minimize their impact is a necessity and scientific requirement. The composition of the inventory of road vehicles will serve as the main input for the construction of the model for air pollution in the Republic of Kosovo.
\end{abstract}

Key word: mobility, air pollution, vehicle emission, environmental impact, public health and safety, ecology. 